\title{
International Farm Prices and the Social Cost of Cheap Food Policies: Comment
}

\author{
John McIntire
}

Peterson's paper "International Farm Prices and the Social Cost of Cheap Food Policies" is a forceful expression of what is becoming a general belief in the profession, that government policies have reduced agricultural production in less developed countries (LDCs). Schultz might be said to be the author of the argument, of which recent examples are Bale and Lutz and some items in their bibliography. Policy implications are that less developed countries could raise agricultural production by improving domestic agricultural incentives, especially output prices.

$I$ argue in this comment that this view, at least as it is quantified in Peterson's paper, can be seriously misleading. I illustrate the point by referring to some countries from sub-Saharan Africa. It is misleading because $(a)$ it is based on a misinterpretation of the price data, $(b)$ it obscures the market structures of many countries, (c) it groups African countries with others where agricultural supply functions are probably more price elastic, and $(d)$ it obscures the role of foreign trade.

\section{The Model of Cheap Food Policies}

Peterson expressed commodity prices (crops and livestock) in wheat-equivalents deflated by fertilizer prices to make them independent of exchange rates. In his figure $1, P_{0}$ is the official producer price ("the prices received by farmers"), $P_{2}$ is the consumer price corresponding to the quantity $Q_{0}$ supplied at $P_{0}$, and $P_{1}$ is the market-clearing price.

Using data from fifty-three developed countries and LDCs, Peterson estimated a supply function with price, technology, and weather variables and found price elasticities between 1.25 and 1.66. Choosing an average price elasticity of supply of 1.27 and one of demand of -1.0 , Peterson solved for the market-clearing price of $P_{1}$ and quantity $Q_{1}$. In equilibrium, net social income would increase by the shaded triangle in his figure 1 . The value of that triangle as a percentage of 1969 national income for the eight African countries in Peterson's sample ranged from $2.5 \%$ to $28.9 \%$ with a mean of $11.4 \%$.

\footnotetext{
John McIntire is principal economist, International Crops $\mathrm{Re}$ search Institute for the Semi-Arid Tropics (ICRISAT), Niamey, Niger.

ICRISAT Journal Article Approval No. 236.

The author acknowledges the comments of Jim Ryan and Tom Walker on an earlier draft.
}

\section{Critique of the Model}

The principal objection to the model is that it uses official FAO (1975) producer prices. It assumes those prices determined supply so as to create a gap between the producer price ( $\boldsymbol{P}_{0}$ in Peterson's figure 1 ) and the consumer price $\left(P_{2}\right)$ in excess of marketing costs. If the gap $\left(\boldsymbol{P}_{2}-\boldsymbol{P}_{0}\right)$ does not exist or if it corresponds to real marketing costs, then there is no justification for the model's social cost calculations. There is good evidence that official producer prices are ignored in African countries, that prices actually received by farmers are higher than official, and that, where a gap exists, it reflects real marketing costs (Jones, CRED). It is also true that official producer prices are usually intended to be minimum prices and that little effort, if any, is made to restrict market prices to these minima.

A second objection is that the proclamation of official prices is insufficient to control prices below market-clearing levels. There must be an effective monopsony to buy crops at less than marketclearing levels. ${ }^{1}$ Without monopsony, the competitive behavior of traders will equilibrate supply and demand prices, reducing the government's market share and eliminating the rent shown as $Q_{0}{ }^{*}\left(P_{2}-\right.$ $P_{0}$ ) in Peterson's figure 1 . While many African governments do have controls on domestic trade, they buy only a small share of output (CRED and the country studies in Pearson, Stryker, Humphreys).

If Peterson is correct about economic rent, then one should find price gaps for major commodities in actual data series roughly equal to those in his model. Table 1 shows values of $P_{2} / P_{0}$ calculated from his model and from market prices for millet in three countries of Peterson's sample and for rice in Senegal. Millet is a major crop in each country, and rice is a major import in Senegal. This provides a good test of the model. Niger, Upper Volta, and Senegal were fourth, ninth, and twelfth among twenty-six LDCs in social costs relative to national income in Peterson's model. Hence, they should be among the greatest beneficiaries of policy reforms.

Except for Senegalese millet, the actual gaps are much smaller than those predicted by the model. This suggests that the official monopsonies were ineffective. It is also true that the gaps might not contain any rent at all. Hence, the relatively small

\footnotetext{
1 Examples might be irrigation projects where levies compel farmers to market output at prices below market levels. Even this structure, in which official monopsony is effective, must provide some incentive to the producer or he would leave the project.
} 
Table 1. Model Price Gaps and Actual Price Gaps, 1968-70

\begin{tabular}{|c|c|c|c|}
\hline & $\begin{array}{l}\text { Model }^{\mathrm{a}} \\
\boldsymbol{P}_{2} / \boldsymbol{P}_{0} \\
\text { (1) } \\
\end{array}$ & $\begin{array}{l}\text { Actual }^{\mathrm{b}} \\
P_{2} / P_{0} \\
(2)\end{array}$ & $\begin{array}{l}\text { Ratio of Model } \\
\text { to Actual } \\
\text { (1)/(2) }\end{array}$ \\
\hline \multicolumn{4}{|l|}{ Niger } \\
\hline Millet & 7.36 & $1.88(1.63)^{\mathrm{c}}$ & $3.91(4.52)^{c}$ \\
\hline \multicolumn{4}{|l|}{ Senegal } \\
\hline Millet & 1.94 & $1.82(1.58)$ & $1.07(1.23)$ \\
\hline Rice & 1.94 & $1.46(1.27)$ & $1.33(1.53)$ \\
\hline \multicolumn{4}{|l|}{ Upper Volta } \\
\hline Millet & 3.02 & $1.92(1.67)$ & $1.57(1.81)$ \\
\hline
\end{tabular}

Note: The actual values of $P_{0}$ for each of the three countries are taken from United Nations 1975, the same source used by Peterson, for the period 1968-70. For Niger, 12 Communauté Financière Africaine francs (FCFA) per kilogram; for rice in Senegal, paddy prices are converted to rice prices by dividing by a milling ratio of 0.65 , and average rice producer price for $1968-70$ was 34.9 FCFA/kg; for millet in Senegal average producer price for 1968-70 was 17.7 FCFA/kg; for Upper Volta millet, average producer price for 1968-70 was 14 FCFA/kg.

a Model values of $\boldsymbol{P}_{2}$ for each country were calculated from quantity change data in column 2 of table 4 in Peterson, from price data in table 1 of Peterson, the benchmark price of $\$ 58.80 /$ metric ton of wheat-equivalent as $P_{1}$, the price elasticity of supply of 1.27 , and the demand price elasticity of -1.0 .

b Actual values of $P$, for millet in Niger are for the years 1967. 1968, and 1971 (values for 1969 and 1970 are lost) from data in CRED for the capital city of Niamey; the value used was 22.6 FCFA/kg, which was the annual average retail price in the three years. Actual values of $\boldsymbol{P}_{2}$ for millet in Senegal for years 1968-70 were 32.3 FCFA/kg; data source is Tuluy. Actual values of $\boldsymbol{P}_{2}$ for rice in Senegal for years $1968-70$ are taken from Tuluy for the capital city of Dakar; the annual average for 1968-70 was 50.8 FCFA/kg. Actual values of millet for years 1968-70 for Upper Volta are annual averages from capital city of Ouagadougou; value was $26.9 \mathrm{FCFA} / \mathrm{kg}$.

c Values in parentheses are calculated assuming that there is a $15 \%$ marketing cost applied to $\boldsymbol{P}_{0}$, in order to reflect the real social costs of delivering farm products to consumers. This $15 \%$ is a conservative estimate of the share of marketing costs in producer prices in these countries.

gaps observed are not grounds to infer that public price policies prevent markets from clearing.

Government price controls can be effective for export crops. Taxes can impose a gap between producer price (marginal cost) and foreign price (average revenue), but Peterson's model denies the relevance of export taxes. Such taxes are particularly important for African tropical crops with little domestic demand and individually inelastic foreign demand. In countries such as Senegal (groundnut oil), Sudan (groundnuts and cotton), Ivory Coast and Ghana (cocoa), export taxes probably do affect the world price. Peterson's model, which sets marginal cost equal to average revenue, undervalues the contribution of such taxes to exporters ${ }^{*}$ welfare.

Another objection is that world prices are irrelevant in countries removed from world markets by transport costs. Consider a market in which transport costs separate import (CIF) prices from export (FOB) prices by the relation

$$
P_{c i f}=P_{f o b}+k \text {, }
$$

where $k$ is transport costs between the FOB and CIF market points. If such markets clear domestically above FOB prices and below CIF prices, international trade does not occur without intervention. The use of FOB or CIF prices as welfare indicators is therefore incorrect.

Such markets exist for crops in Africa (Tuluy; Humphreys and Pearson). In addition, data from the International Livestock Center for Africa (ILCA) illustrate the case of meat markets. In the late 1960 s, FOB meat prices in interior West African countries were $\$ 0.30$ to $\$ 0.40$ per kilogram, and about $\$ 0.70$ in the export markets (Australia or Argentina). The interior West African countries were exporting meat to terminal markets on the West African coast at CIF prices of $\$ 0.80$ to $\$ 1.00$. Because of transport costs, interior markets cleared at prices well below world export prices. Raising prices in the interior to world export levels would have created excess supply in the interior. Using world export prices as a welfare indicator is again incorrect.

The model also overestimates African price elasticities of supply. A review of such elasticities in African smallholder agriculture, the dominant type, shows few single-crop elasticities as high as Peterson's aggregate elasticity. The single-crop average is about 0.7 (Helleiner). The literature also suggests that response to price is greater where irrigation and modern varieties are more common (Scandizzo and Bruce). The share of irrigated area in arable area in the eight African countries was $1.0 \%$ in 1969 , compared to $12.0 \%$ in the other nineteen countries of Peterson's sample (United Nations 1980).

Though Peterson's model does not consider foreign trade, one of his more important conclusions is: "Indeed one might go so far as to say that if farm prices in the LDCs were to approach world market levels, these countries likely would become substantial exporters of agricultural products" (pp. 18-19). African countries imported large quantities of food in the 1960s and 1970s. This is excluded from Peterson's market structure and contradicts his empirical results.

Consider a market with foreign trade. Peterson's figure 1 can be imagined to present such a market with international price of $P_{1}$. If governments impose $P_{0}$ on producers, importers would exploit the gap $\left(P_{2}-P_{1}\right)$ and import the quantity $\left(Q_{1}-Q_{0}\right)$, lowering the consumer price to $P_{1}$. Without trade controls [such as a ban on imports or a specific tariff of $\left.\left(P_{2}-P_{1}\right)\right]$, only the lower part of the shaded triangle can be counted among the social costs of cheap food policies.

The model is also politically unrealistic. Why would governments tax producers and consumers, so that both are worse off in Peterson's model than in the equilibrium market? It might be more reasonable to assume a market in which imports $\left(Q_{2}-Q_{0}\right)$ are subsidized at $P_{0}$ in figure 1 . Producers are worse 


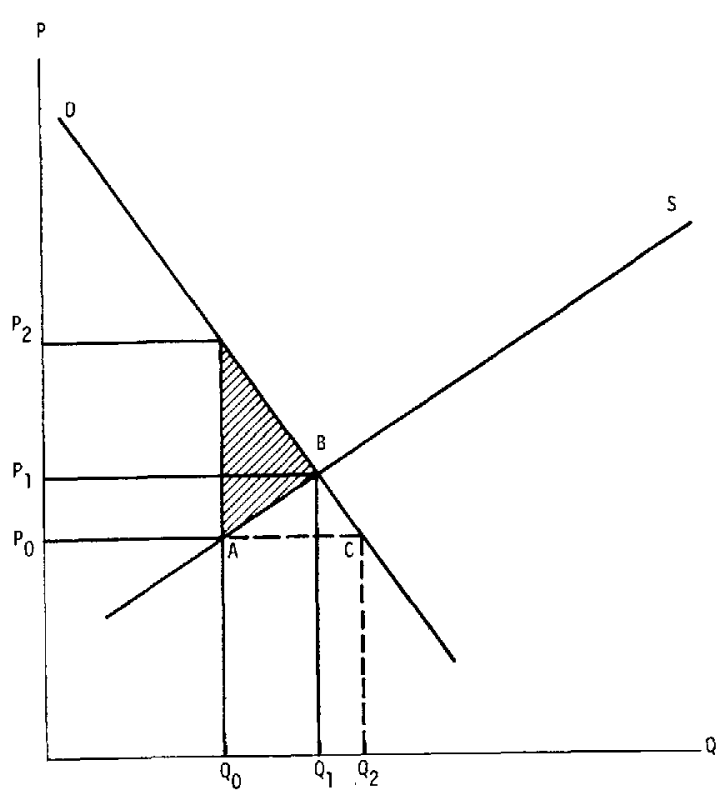

Figure 1. The social cost of cheap food policies (from Peterson)

off than in Peterson's equilibrium market where they sell $Q_{1}$ at $P_{1}$, but consumers are better off than if they consume $Q_{1}$ at $P_{1}$. If imports $\left(Q_{2}-Q_{0}\right)$ are subsidized, producer's income is equal to that in Peterson's disequilibrium market because they sell $Q_{0}$ at $P_{0}$, but consumers are better off because they consume $Q_{2}$ at $P_{0}$, not $Q_{0}$ at $P_{2}$.

Governments careful of consumers' interests might find import subsidies a rational policy. While such subsidies reduce producer income and increase imports, the net income effects of removing the subsidies and allowing markets to clear at price $P_{1}$ would be different from those in Peterson's model. In Peterson's model the shaded triangle of figure 1 is a cost of cheap food policies. The triangle $\mathrm{ABC}$ in figure 1 here is a gain from another type of cheap food policy, however. It is not a net gain, which would have to include the costs of taxes used to pay the import subsidy $\left(P_{1}-P_{0}\right)$. The difference between Peterson's model and the subsidized imports model in figure 1 is that no one gains in Peterson's model and hence no one would support the policy, but consumers would support the cheap food policy of subsidized imports.

\section{Conclusions}

The evidence has recently become strong that agricultural goods are undervalued in many LDCs. While there is uncertainty about the income gains from policy reforms (because of uncertainty about the price elasticities), such gains probably would be positive. Most of this evidence is from Asia and Latin America, however, not from Africa.
Detailed studies in Africa show mixed results (CRED; Pearson, Stryker, Humphreys) and suggest that models using official prices and/or world prices are inapplicable in some markets. Peterson's model, based on official producer prices and on a simplified world price, gives results inconsistent with prices in three of four African markets. This suggests that Peterson's model exaggerates gains from price reforms in those countries. The model also fails to consider the effects of imports on the welfare implications of cheap food policies. Finally, his model assumes an irrational political economy in which cheap food policies benefit no one-both producers and consumers would lose from such policies.

While this comment produces evidence from a small number of countries, it should apply to most LDCs. Further research on price distortions will have a high return, but only if one considers different market structures and the distributions of gains among classes of producers and consumers.

\section{[Received July 1982; revision accepted April 1983.]}

\section{References}

Bale, Malcolm D., and Ernst Lutz. "Price Distortions in Agriculture: An International Comparison." Amer.J. Agr. Econ. 63(1981):8-22.

Center for Research on Economic Development (CRED). Marketing, Price Policy, and Storage of Food Grains in the Sahel, 2 vols. Ann Arbor: University of Michigan, 1977.

Helleiner, Gerald K. "Smallholder Decision Making: Tropical African Evidence." Agriculture in Development Theory, ed. Lloyd G. Reynolds, pp. 27-52. New Haven CT: Yale University Press, 1975.

Humphreys, Charles P., and Scott R. Pearson. "Choice of Technique in Sahelian Rice Production." Food Res. Inst. Stud. 17(1979): 100-35.

International Livestock Center for Africa (ILCA). ILCA Bulletin No. 3. Addis Ababa, Ethiopia, 1979.

Jones, William O. Marketing Staple Food Crops in Tropical Africa. Ithaca NY: Cornell University Press, 1972.

Pearson, Scott R., J. Dirck Stryker, and Charles P. Humphreys. Rice in West Africa: Policy and Economics. Stanford CA: Stanford University Press, 1981.

Peterson, Willis L. "International Farm Prices and the Social Cost of Cheap Food Policies." Amer. J. Agr. Econ. 61(1979): 12-21.

Scandizzo, Pasquale L., and Colin Bruce. "Methodologies for Measuring Agricultural Price Incentive Effects." Washington DC: World Bank Staff Work. Pap. No. 344, 1980.

Tuluy, A. Hasan. "Comparative Costs and Incentives in 
Senegalese Rice Production." Rice in West Africa: Policy and Economics, ed. Scott R. Pearson, J. Dirck Stryker, and Charles P. Humphreys, pp. 263-95. Stanford CA: Stanford University Press, 1981.
United Nations Food and Agriculture Organization (FAO). Agricultural Producer Prices, 1961-1970. Rome, 1975.

Production yearbook (1979). Rome, 1980. 